\title{
Financiële integratie en kredietverlening aan MKB's
}

\section{Hans Degryse, Fabiana Penas en Steven Ongena}

SAMENVATTING In deze bijdrage gaan we na of kleine en middelgrote bedrijven negatief beïnvloed worden door de toenemende integratie van de Europese financiële sector. Financiële integratie, in de Europese banksector door meer concurrentie en door consolidatie, kan de financiering van jonge, innoverende en kleine bedrijven in gevaar brengen. Wanneer we echter het huidige bewijsmateriaal samenvatten, besluiten we dat het hoogstens overgangsproblemen betreft.

\section{Inleiding}

Leidt financiële integratie tot slechtere kredietvoorwaarden voor het Midden en Klein Bedrijf (MKB's)? Het MKB klaagde de afgelopen jaren over moeilijkheden bij het verkrijgen van leningen tegen een redelijke rentevoet. In deze bijdrage nemen we de huidige theorie en het recente bewijsmateriaal over dit onderwerp onder de loep. Wij wijzen op de problemen die financiële integratie kan creëren voor innovatie en meer in het bijzonder voor "radicale" innovaties. Financiële integratie, door meer concurrentie en consolidatie in de Europese banksector, kan de financiering bedreigen van de bedrijven die voor ingrijpende vernieuwing zorgen zoals startende bedrijven en andere kleine of jonge ondernemingen.

Om meer radicale innovaties te genereren, hebben

Professor Dr. H. Degryse is hoogleraar en houder van de TILECAFM Leerstoel in financiële regelgeving aan de Universiteit van Tilburg, hoogleraar aan de K.U. Leuven, en CESIfo fellow. Dr. M. F. Penas is universitair docent aan de Universiteit van Tilburg. Professor Dr. S.R.G. Ongena is hoogleraar in empirical banking aan de Universiteit van Tilburg en CEPR fellow. We ontvingen waardevolle opmerkingen van de redactie: Chris Knoops (hoofdredacteur), Ivan Mortimer-Schutts en Marco Da Rin. ${ }^{1}$ kleine ondernemingen behoefte aan toegang tot financiële middelen zodat ze kunnen gedijen in Europa. Maar hoe kunnen kleine en startende ondernemingen worden gefinancierd? Of hoe kan de financiële integratie van de Europese banksector deze financiering eventueel bedreigen? Een scherpere concurrentie tussen banken kan de fundamentele en tijdelijke risicospreiding tussen bank en innovator ontwrichten, terwijl een consolidatiebeweging in de bankwereld megabanken kan creëren die niet geneigd of niet in staat zijn de leningsaanvragen van kleine ondernemingen op de juiste wijze te beoordelen en te waarderen. Het bestaande bewijsmateriaal in ogenschouw nemend, stellen we echter dat de toenemende bancaire concurrentie en relatiebankieren niet noodzakelijk in tegenspraak met elkaar zijn en dat andere bestaande of nieuwe banken een alternatief kunnen zijn of worden voor bedrijven die aanvankelijk moeilijkheden hebben leningen te bekomen. Het klopt dat alle negatieve effecten van consolidatie op lange termijn waarschijnlijk te vermijden zijn indien de ontwikkeling van alternatieve financieringskanalen en -vormen niet in extreme mate belemmerd wordt. Dergelijke hinder kan bijvoorbeeld afkomstig zijn van toezichthouders of van mededingingsbeleid die de voorkeur geven aan de creatie van lokale, nationale en zelfs Europese 'kampioenen'.

De rest van het artikel wordt als volgt gestructureerd. Paragraaf 2 bespreekt de impact van de integratie in de Europese banksector op de financiering van innovatie. In paragraaf 3 bestuderen we de rol van alternatieve financieringsbronnen zoals durfkapitaal. Sectie 4 concludeert. Een goede leidraad voor de rest van de bijdrage is Figuur 1, die onze argumentatie schematisch samenvat ("wit op zwart" duiden we ook de respectieve paragrafen aan).

Deregulering en technologie zijn de stuwers die de integratie, en in het bijzonder de concurrentie en consolidatie van de Europese banksector bevorderen 
(paragraaf 2.1). Verscherpte concurrentie kan problemen scheppen bij de financiering van innovatie, omdat banken dan weigerachtig kunnen staan tegenover het investeren in relaties (paragraaf 2.2) die noodzakelijk kunnen zijn bij de financiering van kleine en innovatieve bedrijven. Consolidatie in de banksector kan de financiering van innovatie verder belasten, vooral op de korte termijn (2.2.1), omdat grotere banken vaak niet de interesse of de kennis in huis hebben om de kleine en innovatieve bedrijven te voorzien van krediet. Op de lange termijn zijn de negatieve effecten waarschijnlijk eerder beperkt (2.2.2), omdat bestaande en nieuwe banken de financiering van deze bedrijven op zich zullen nemen en omdat alternatieve financieringsbronnen, in het bijzonder durfkapitaal (paragraaf 3), reeds belangrijk zijn en nog belangrijker kunnen worden. Samenvattend kan gesteld worden dat verscherpte concurrentie en consolidatie in de banksector daarom niet noodzakelijk dienen te leiden tot een verzwakking van de financiering van innovatie en economische groei (paragraaf 4 ).

\section{Impact van de integratie in de Europese banksector op de financiering van innovatie}

In deze paragraaf bekijken we hoe concurrentie en consolidatie in de Europese banksector van invloed kan zijn op de financiering van innovatie (zoals reeds gezegd biedt figuur 1 een schematisch overzicht). We kijken ook even naar alternatieve financieringsbronnen, in het bijzonder durfkapitaal, en bespreken de impact die consolidatie in de financiële sector kan hebben op de rol die banken spelen in de markt voor durfkapitaal. Het lijkt echter het meest logisch om ons eerst te concentreren op financiering door banken en de directe impact ervan op de financiering van het MKB. Een uitgebreide literatuur die minstens teruggaat tot Fama (1985), stelde reeds dat banken uniek zijn en dat andere financieringsmiddelen voor kleine, jonge en innovatieve ondernemingen hoogstens imperfecte substituten vormen. Alternatieve financieringsmiddelen voor innoverende bedrijven lijken in Europa bovendien nog steeds onderontwikkeld. Hierop komen we terug aan het einde van deze paragraaf.

\subsection{Deregulering en technologie bevorderen concurrentie en consolidatie}

Zowel deregulering als technologie (aangeduid als stuwers in figuur 1) beïnvloeden fundamenteel de Europese banksector. De meeste restricties zijn intussen verwijderd en de Europese bankmarkt is in principe toegankelijk voor alle in de Europese Unie erkende banken. Hoewel er verschillende economische grenzen blijven bestaan, bestaat er significant bewijs voor de heilzame effecten van deregulering op concurrentie zowel in het algemeen als in het bijzonder voor Europa.

Ontwikkelingen in de communicatietechnologie hebben de "tyranny of distance" ondermijnd (Petersen en Rajan, 2002) en zo concurrentie in bankmarkten verscherpt. De gevolgen van technologie voor concurrentie zijn niet eenduidig. De betere toegang van banken tot informatie zal enerzijds leiden tot meer concurrentie en lagere interestvoeten, maar anderzijds zal de hogere bekwaamheid om informatie te behandelen mogelijk informatiewinst creëren met als gevolg hogere interestvoeten en winsten. Bovendien dient de vooruitgang in de communicatietechnologie en een grotere informatiecapaciteit niet te betekenen dat er meer uitwisseling van informatie, en dus meer concurrentie, plaatsvindt.

Deregulering en technologische vooruitgang stimuleren niet enkel concurrentie, maar bevorderen ook consolidatie in de banksector. In tegenstelling tot de Verenigde Staten, waar deregulering leidde tot consolidatie van banken over de grenzen van de verschillende "States" heen (met bijna geen effect op lokale concentraties), vertaalde deregulering in Europa zich tot nu toe hoofdzakelijk in nationale fusies, waarbij zogenaamde "nationale kampioenen" en sterker geconcentreerde bankmarkten ontstonden. Omwille van de "winner's curse" (dat wil zeggen: het winnend bod betaalt altijd teveel), kunnen buitenlandse banken er van afzien om in de markt te stappen. Wanneer banken binnen een land fuseren, sterk in omvang toenemen en diversifiëren, kan de "winner's curse" minder belangrijk worden. Bovendien kan nationaal mededingingsbeleid uiteindelijk verdere binnenlandse consolidatie verhinderen en integratie over de grenzen heen aanmoedigen. "Nationale kampioenen" zullen om die reden bijna onvermijdelijk transformeren in "Europese kampioenen".

Technologische vooruitgang, in het bijzonder op het vlak van communicatie en informatieverwerking, wijzigen op grote schaal de bestaande toepassingen in de banksector (Berger, 2003), vooral voor (1) het opvolgen en het risicobeheer van leningen, (2) het verlenen van de traditionele bankdiensten, bijvoorbeeld door verbeteringen in het voorspellen van het betalingsgedrag via "credit scoring", (3) het personeelsbeheer en (4) het aanbieden van nieuwe diensten over het Internet. Schaalvoordelen voor elk van deze punten lijkt de bankconsolidatie te hebben bevorderd (Strahan, 2005). Grote banken implementeren nieuwe technologieën zoals credit scoring, 
Figuur 1 Integratie en Kredietverlening aan MKBs

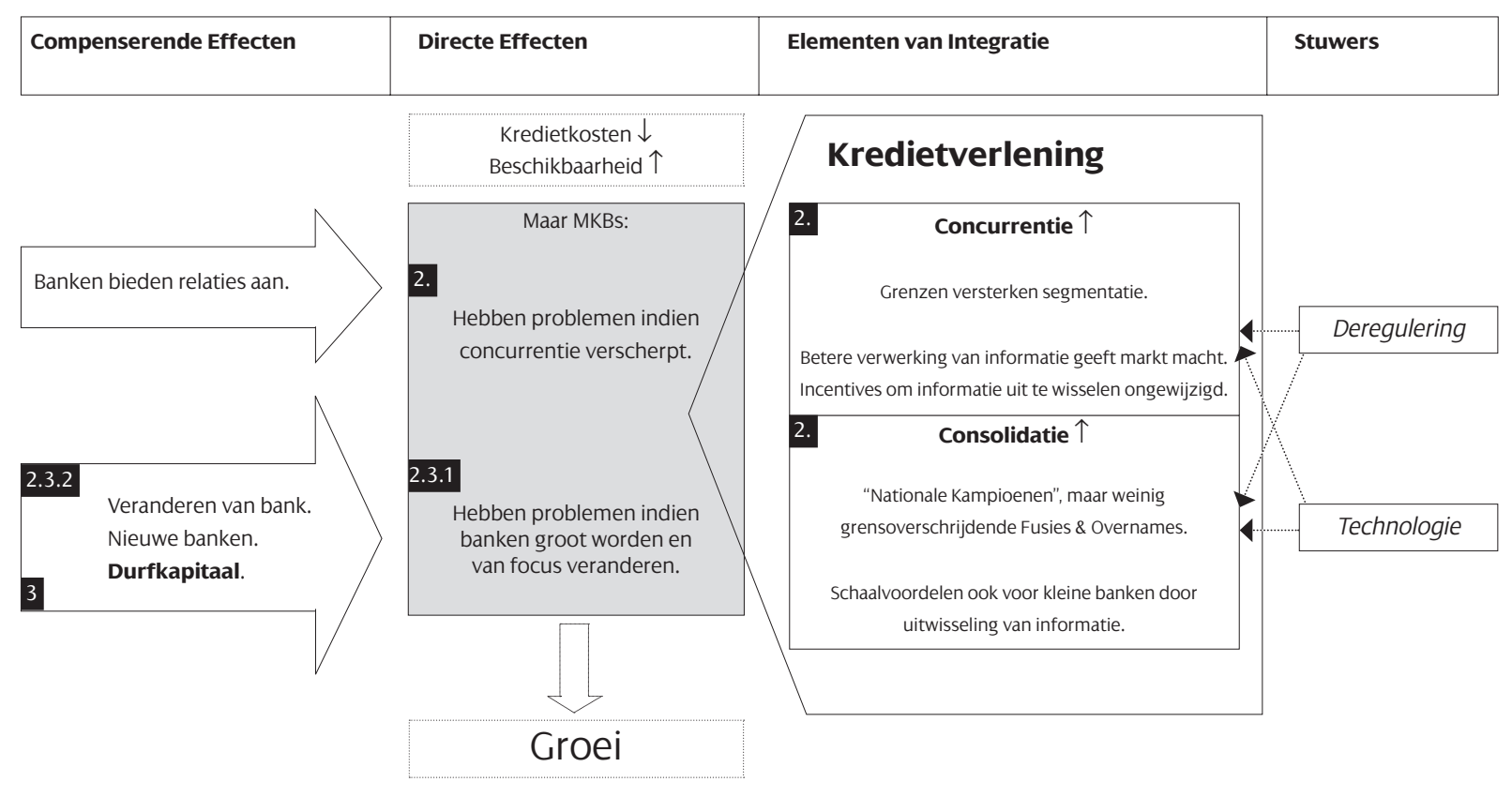

Bron: Degryse, Ongena en Penas (2006)

securitisatie en internetbankieren inderdaad sneller dan kleinere banken, terwijl ze ook oudere technologieën zoals telefoon en fax eerder invoerden.

\subsection{Impact van concurrentie op de financiering van innovatie}

De impact van een verscherping van de concurrentie, vaak gemeten met een maatstaf van concentratie, in de bankmarkt (aangeduid als het eerste element van integratie in figuur 1) op rentevoeten voor bankleningen werd al uitvoerig onderzocht (Gilbert en Zaretsky, 2003). Hoewel het effect meestal positief is, varieert de grootte van het effect van de bancaire concentratie op interestvoeten aanzienlijk (Degryse en Ongena, 2006). Desalniettemin lijkt de conclusie te zijn dat meer concurrentie, en dus een lagere concentratie op de bankmarkt, lagere kredietkosten met zich meebrengt.

Maar er zijn echter andere dimensies die men moet bestuderen om te oordelen over het effect van concurrentie in de banksector op de financiering van innovatie. Zo zijn de uiteindelijke effecten van interbancaire concurrentie niet enkel afhankelijk van de rentevoet, maar ook van de beschikbaarheid van bankkrediet voor verschillende types van ondernemingen. Petersen en Rajan (1995) modelleren hoe vooral ondernemingen met onzekere toekomstige cashflows negatief beïnvloed worden door de concurrentie tussen banken. Banken kunnen weigerachtig staan tegenover het investeren in relaties wanneer de aanvankelijke verliezen op leningen misschien nooit meer kunnen worden terugverdiend (aangezien ondernemingen later een lage rentevoet kunnen verkrijgen op een concurrerende banken- of financiële markt).

Petersen en Rajan (1995) leverden ook empirisch bewijs van het effect van concurrentie in de bankmarkt, zowel op de interestvoet als op de beschikbaarheid van krediet. Ze tonen aan dat jonge ondernemingen - met onzekere toekomstige cashflows - in minder concurrerende, dat wil zeggen meer geconcentreerde, bankmarkten in de VS tegen significant lagere rentevoeten kunnen lenen dan ondernemingen in meer concurrerende bankmarkten. De interestvoeten dalen met meer dan $150^{* *}$ basispunten voor nieuwe bedrijven indien de HerfindahlHirschman Index $(\mathrm{HHI})^{2}$ met 0,10 toeneemt. $^{3} \mathrm{Ze}$ tonen tevens het bestaan aan van een enigszins makkelijkere toegang tot bankkrediet in meer geconcentreerde markten, maar zelfs voor jonge bedrijven lijken de effecten economisch gezien van bescheiden aard en statistisch gezien niet altijd significant. Een toename in de HHI van 0,10 verhoogt het betaalde percentage handelskrediet voor vervaldag met ongeveer $1,5^{* * *}$ tot $3^{* * *}$ procent voor alle ondernemingen en met ongeveer $2^{\star}$ tot 8 procent voor jonge ondernemingen. 
Het is echter niet duidelijk hoe het bewijs dat Petersen en Rajan (1995) leveren voor de VS zich vertaalt in Europese context. Enerzijds vinden Herrera en Minetti (2005) voor een steekproef van 4.000 Italiaanse verwerkende bedrijven dat de waarschijnlijkheid dat ondernemingen innoveren positief beïnvloed wordt door de duur van de kredietrelatie met de bank; dit geeft het belang aan die bank-ondernemingsrelaties kunnen hebben bij het kanaliseren van middelen naar de sterkst innoverende projecten. Anderzijds vinden Angelini, Di Salvo en Ferri (1998) voor een steekproef van kleine Italiaanse bedrijven geen economisch significant effect op (de beoordeling van) de beschikbaarheid van krediet.

Giannetti en Ongena (2005) gebruiken een uitgebreid panel met observaties van bijna 60.000 boekjaren van beurs- en niet-beursgenoteerde ondernemingen in Oost-Europese markten om een verschillenanalyse te maken van de aanwezigheid van buitenlandse banken op groei en financiering. Ze concluderen dat leningen uitgegeven door buitenlandse (lokaal aanwezige) banken bankkrediet in het land goedkoper (de interestbetalingen door de bedrijven dalen) en breder toegankelijk maken (het gebruik van handelskrediet daalt), maar dat deze positieve effecten minder manifest aanwezig zijn voor kleine ondernemingen. Hoewel het de binnenlandse concurrentie stimuleert, hebben buitenlandse banken er mogelijk minder belang bij om "soft" informatie te verwerven en zich om de lange termijnrelaties met kleine ondernemingen te bekommeren.

Een extra moeilijkheid in het interpreteren van resultaten is het bestaan van aanzienlijke verschillen in de eigenschappen en de graad van ontwikkeling van de Europese nationale bankmarkten. We kunnen het aantal relaties dat een bedrijf met banken heeft als voorbeeld nemen. Ongena en Smith (2000) toont het bestaan aan van grote verschillen tussen landen in het aantal relaties. Ze concluderen dat het aantal relaties ruwweg toeneemt van noord naar zuid, van 1 in noordelijk tot 15 in zuidelijk Europa. Verder bestaan er ook aanzienlijke verschillen tussen landen wat betreft de duur van de relatie. Bij kleine Amerikaanse en Belgische ondernemingen zien we bijvoorbeeld een gemiddelde duur van de relatie tussen vijf en tien jaar, terwijl kleine Italiaanse en Franse ondernemingen vijftien jaar of meer optekenen.

Hoewel theoretisch onderzoek dit verschil tussen verschillende landen verder analyseert via de basiskarakteristieken van bedrijf-bankrelaties (Carletti, 2004; Detragiache, Garella en Guiso, 2000; en Von Rheinbaben en Ruckes, 2004, bijvoorbeeld), is het duidelijk dat dit essentiële aspect van een nationale bankenmarkt kan bepalen hoe wijzigingen in de intensiteit van concurrentie op de markt de prijs en beschikbaarheid van krediet voor kleine en innoverende ondernemingen beïnvloedt. Als kleine ondernemingen bij het opstarten over verscheidene relaties beschikken, dan beïnvloeden wijzigingen in de intensiteit van concurrentie niet noodzakelijk substantieel hun financiering. Wanneer anderzijds het gebrek aan concurrentie toelaat dat kleine en innoverende bedrijven weinig en intense relaties onderhouden, dan kan een scherpere concurrentie niet alleen deze relaties onder druk zetten en zelfs afbreken, maar tevens de financiering van de bedrijven in gevaar brengen. De bedrijven kunnen bovendien nog meer kredietproblemen ervaren indien hun belangrijkste banken lijden onder de concurrentiedruk en over de kop gaan. De kwestie van beëindigen van bedrijfbankrelaties door noodlijdende banken wordt behandeld in de volgende paragraaf.

\subsection{De impact van consolidatie op de financiering van innovatie}

\subsubsection{Directe effecten van consolidatie}

Volgens de gangbare opvatting moeten fusies die zorgen voor een grotere marktmacht enerzijds de prijzen laten stijgen of de kwaliteit van dienstlevering laten dalen, wat resulteert in een lagere welvaart voor de consumenten (consolidatie is aangeduid als het tweede element van integratie in figuur 1; de directe effecten zijn ook aangeduid). Anderzijds moeten efficiencywinsten de prijzen laten dalen of de kwaliteit van dienstlevering laten stijgen, wat de welvaart van de consumenten bevordert. Samenvattend kunnen we stellen dat klanten benadeeld worden door fusies indien het effect van de toegenomen marktmacht opweegt tegen de winst die behaald kan worden door efficiënter te handelen en die wordt doorberekend aan ondernemingen die bij banken lenen.

Er zijn evenwel andere scenario's mogelijk. Marktmacht op de bankmarkt kan bijvoorbeeld bepaalde types van leners ten goede komen. Zoals al eerder werd aangegeven, stellen Petersen en Rajan (1995) dat geconcentreerde kredietmarkten vereist zijn voor de financiering van bedrijven met hoogst onzekere toekomstige cashflows. Concurrentie kan evenwel ook de investeringen in leningen op basis van relaties laten stijgen. Boot en Thakor (2000) zien relatieleningen als een manier om een gedifferentieerd product aan te bieden dat in mindere mate aan prijsconcurrentie onderhevig is.

Zelfs in een concurrerende markt hoeven fusiegerela- 
teerde efficiencywinsten niet te leiden tot een welvaartsverbetering voor alle klantentypes (Karceski, Ongena en Smith, 2005). Wanneer bijvoorbeeld bij een overname de over te nemen bank beschouwd wordt als ondergewaardeerd doordat ze slecht geleid wordt, verkrijgen haar klanten mogelijk leningen tegen interestvoeten onder de kostprijs. Een deel van de verklaring voor het slecht presteren van de over te nemen bank is dat het leningen verschaft die niet correct geprijsd zijn, dat wil zeggen waarvan de interestvoet te laag is voor de genomen risico's. Het nieuwe management zal noodgedwongen de interestvoeten voor deze klanten moeten verhogen of zelfs verder krediet volledig moeten weigeren.

Zelfs wanneer leners winstgevend zijn voor hun banken, kunnen consoliderende instellingen inefficiënties benutten die bepaalde lenertypes negatief beïnvloeden. Berger en Udell (1996), Peek en Rosengren (1996), en Sapienza (2002) concluderen dat naarmate een bank in omvang toeneemt, ze ernaar neigt sterker de klemtoon te leggen op de financiering van grotere ondernemingen. Stein (2002) geeft een theoretische verklaring voor dit "grootte-effect bij leningen", waarbij grote banken eerder aan grote ondernemingen lenen en kleine banken eerder aan kleine ondernemingen.

Grote banken die een sterke, centrale en hiërarchische structuur hebben (met veel verschillende niveaus van besluitvorming) doen het alleen goed wanneer informatie "hard" genoeg is om vrij binnen de bank te circuleren (Stein, 2002). Anderzijds hebben enkel bedienden bij kleine banken de juiste prikkels om "soft" informatie te verzamelen en er voordeel uit te halen. Nu is het zo dat "soft" informatie moeilijk door te geven is, wat een probleem vormt binnen de "hiërarchische banken", maar dat dit type informatie nu net vereist is om relatiebankieren te laten slagen. ${ }^{4}$ De organisatiestructuur van kleine, gedecentraliseerde banken is daarom geschikt voor het nemen van beslissingen over leningen op basis van "soft" informatie, zoals vertrouwen en reputatie, die beslissend is bij het lenen aan kleine ondernemingen. Indien bankconsolidatie tot een grotere organisatorische complexiteit leidt, impliceert de analyse van Stein dat fuserende banken efficiencywinsten zullen betrachten door zich te concentreren op het lenen aan grote ondernemingen. De kleine leners van fuserende banken kunnen bijgevolg geschaad worden bij het groeien en complexer worden van banken, veronderstellend dat er geen alternatieve financieringsbronnen zijn. Recent bewijsmateriaal voor Italië (Bonaccorsi di Patti en Gobbi, 2005) toont aan dat Italiaanse MKB's die lenen bij een bank die een over- namebod uitbrengt of waarop een overnamebod wordt uitgebracht, tijdelijk een terugval in krediet ondervinden van respectievelijk ongeveer 1,5 procent en 2 procent. Als bovendien de relatie tussen onderneming en fuserende bank wordt verbroken, bedraagt de tijdelijke kredietdaling 9 procent. De studie concludeert echter ook dat de vermindering in krediet slechts tijdelijk is en na drie jaar volledig is tenietgedaan.

Hierbij aansluitend kunnen leners bij overgenomen banken een negatief effect ondervinden wanneer de fuserende bank de strategische focus of de eigenschappen van de overnemende bank aanneemt. Overnames wijzigen vaak de personeelspolitiek ten voordele van werknemers en managers van de verwervende onderneming. Overnames resulteren ook vaak in de invoering van de organisatorische structuur en het beleid van de overnemer. Het ontslag van belangrijke werknemers kan bestaande leenrelaties verstoren. Wanneer een bankfusie uitmondt in een gewijzigd leengedrag van de overgenomen bank, kan het nieuwe, post-fusie leningsbeleid leners vertrouwd met het voorheen heersende systeem verwarren of ontevreden stemmen. Degryse, Masschelein en Mitchell (2005) analyseren bijvoorbeeld Belgische bankfusies en stellen inderdaad dat (1) kredietnemers van de overgenomen banken met grotere waarschijnlijkheid hun verbintenis stopzetten en (2) dat de kredietbeschikbaarheid voor leners, die enkel een relatie hebben met de overgenomen bank en bij die bank blijven, negatief beïnvloed wordt. In de volgende subparagraaf bestuderen we de langetermijneffecten van consolidatie.

\subsubsection{Langetermijneffecten van consolidatie}

Het is niet duidelijk of we op lange termijn een negatieve impact van consolidatie op de financiering van innovatie moeten verwachten daar er een aantal compenserende effecten kan spelen (de compenserende effecten zijn ook aangeduid in figuur 1).

Ten eerste tonen bijvoorbeeld Berger, Saunders, Scalise en Udell (1998) aan dat de aanvankelijke daling in leningen aan het MKB na een fusie of overname gecompenseerd wordt door krediet dat andere banken in dezelfde lokale markt verschaffen. Hiernaast stellen Garmaise en Moskowitz (2006) vast dat de negatieve effecten van een daling in concurrentie na grote bankfusies (grote fusies worden verondersteld exogeen te zijn voor de bestudeerde lokale markt) na drie jaar zijn verdwenen. Hetzelfde lijkt waar te zijn voor deposito's en leningen in de jaren na Italiaanse bankfusies (Focarelli en Panetta, 2003; Bonaccorsi di Patti en Gobbi, 2005). 
Ten tweede kan de toetreding van nieuwe banken gestimuleerd worden door grote verschillen in de krediet- en deposito-interestvoeten. Op dit punt is er bewijsmateriaal beschikbaar uit de VS. Berger, Bonime, Goldberg en White (2004) tonen bijvoorbeeld aan dat de creatie van nieuwe banken hoger is na consolidatie, terwijl DeYoung, Goldberg en White (1999) vaststellen dat nieuwe banken hun leningen concentreren op kleine ondernemingen. Het aantal nieuwe banken lijkt in Europa echter nogal beperkt vergeleken met de VS. Vooral voor kleine ondernemingen kan dit een bron van zorgen zijn aangezien nieuwe banken, klein startend, bereid kunnen zijn kleine bedrijven te financieren en er relaties mee te ontwikkelen. Potentiële concurrentie bepaalt doelmatige concurrentie vooral doordat (buitenlandse) banken de markt kunnen betreden en doordat beperkingen op bankactiviteiten verminderen. Rapporten voor de VS geven weer dat tijdens de periode 1985-2003 2.275 nieuwe banken werden opgericht (Mortimer-Schutts, 2005). Dit suggereert dat Amerikaanse bankmarkten toegankelijk zijn aangezien nieuwe banken zich met succes richten op specifieke lokale markten en activiteiten. Slechts 34 nieuwe afdelingen van EU-banken en 11 nieuwe banken werden onder directe controle van de Franse toezichthoudende autoriteiten opgericht in de periode 19952004. Ongeveer 105 aanvragen om bankactiviteiten te verrichten werden tijdens de periode 2001-2004 met succes bij de Duitse regelgevende instantie ingediend (Mortimer-Schutts, 2005).

Hoe beinvloedt Basel II de potentiele toetreding van kleine banken die zich specialiseren in het MKB? Basel II laat de keuze aan de banken om te kiezen voor de "standardized approach" of de "internal ratings based approach". De "internal ratings based approach" leidt voor verschillende banken tot lagere kapitaalsverplichtingen dan de "standardized approach". De "internal ratings based approach" echter wordt meestal enkel gekozen door grotere banken wegens substantiele aanloopkosten en de behoefte aan voldoende schaal. We kunnen dan ook verwachten dat toetreding van kleine banken die zich specialiseren in het MKB minder waarschijnlijk wordt tengevolge van Basel II.

Claessens en Laeven (2004) onderscheiden toegangsen activiteitsbeperkingen als de belangrijkste determinanten van potentiële concurrentie. Zij berekenen de Panzar en Rosse H-statistiek voor 50 landen voor de periode 1994-2001 en stellen vast dat de meeste bankmarkten eigenlijk gekarakteriseerd worden door monopolistische concurrentie met een $\mathrm{H}$-statistiek variërend tussen 0,6 en 0,8 en dat toegangs- en activi- teitsbeperkingen leiden tot een lagere $\mathrm{H}$-statistiek en dus tot minder concurrentie. ${ }^{5}$

Ten derde kunnen innovatieve ondernemingen meer en meer beroep doen op alternatieve financieringsbronnen, bijvoorbeeld durfkapitaal, een item waar we in de volgende paragraaf dieper op ingaan.

\section{Durfkapitaal}

Durfkapitaal (en andere marktgebaseerde financieringsvormen) zijn goed afgestemd op de financiering van kleine ondernemingen die radicale innovaties nastreven. Wanneer bijvoorbeeld een nieuwe technologie wordt geïntroduceerd bestaat er niet alleen onzekerheid omtrent de slaagkansen, maar ook over welke managementstrategie het best kan worden toegepast. Investeerders die van mening verschillen zijn kenmerkend voor dergelijke projecten. Allen en Gale (1999) argumenteren dat markten aanzienlijke voordelen hebben ten opzichte van geintermedieerde financiering indien er bij de opstart geen unaniem oordeel bestaat onder investeerders:

"A large number of people participate directly in the investment decision. This is costly because each investor has to acquire information to make the decision, but it has the great advantage that each investor makes his own decision based on his own information and his own prior. This ability to agree to disagree allows innovative projects to be financed."

De mate waarin om het even welk van deze alternatieven zal reageren op consolidatie, en nieuwe financieringsbronnen zal verstrekken aan kleine en innoverende bedrijven is natuurlijk afhankelijk van het gevoerde beleid en de economische situatie. Positief voor innovatie is het feit dat de Europese markt voor durfkapitaal nagenoeg geïntegreerd is (misschien zelfs meer dan de traditionele bankmarkt!). Ongeveer een kwart van alle participatiemaatschappijen heeft partners uit derde landen en een kwart van de investeringen gebeurt in derde landen, met de VS als populairste locatie voor buitenlandse investeringen. Tevens had een derde van alle Europese durfkapitalisten enige werkervaring in de VS. Tot slot investeren nieuwe toetreders in de sector voor durfkapitaal meer in de aanvangsfase, ze volgen hun investeringen meer op, ze hebben in het verleden meer professionele ervaring opgedaan en ze hebben met grotere waarschijnlijkheid een bedrijfskundige opleiding genoten en een Mastergraad behaald.

Er zijn echter nog andere institutionele en regelgevende factoren die een sleutelrol spelen in de toename in innovatie (Da Rin, Nicodano en Sembenelli, 2005). 
De ervaringen van veertien Europese landen tussen 1988 en 2001 werden geanalyseerd om na te gaan wat de drijfveren zijn achter hogere "ratio's of innovation" (gedefinieerd als het aandeel van hoogtechnologische investeringen en investeringen in de eerste fases ten opzichte van de totale investeringen in durfkapitaal). Ze stellen vast dat de belangrijkste determinanten van de hogere ratio's het bestaan is van (1) mogelijkheden voor durfkapitalisten om uit te treden en te cashen zoals het bestaan van effectenbeurzen waar ondernemende bedrijven kunnen noteren, (2) een grotere flexibiliteit op de arbeidsmarkt en (3) een daling in de belasting op de vermogensgroei van ondernemingen. ${ }^{6}$ De praktische beleidsimplicaties voor de verschillende spelers op financiele markten zijn overduidelijk: marktparticipanten hebben belang in het opzetten en actief organiseren van een liquide markt waar nieuwe bedrijven kunnen noteren.

Veel van de eigenschappen van Europees durfkapitaal zijn gerelateerd aan het feit dat Europa's economie op banken stoelt. Hierdoor kan een consolidatie van de bankwereld, die tot grotere en meer gediversifieerde financiële instellingen leidt, banken toelaten om de fondsen te verhogen die ze aanwenden voor zeer riskante activiteiten zoals investeringen op de markt voor durfkapitaal. Nochtans gedragen banken zich in deze markt strategisch eerder als volgers dan als leiders. Werk uit de VS (Hellmann, Lindsay en Puri, 2005) en Europa (Bottazzi, Da Rin en Hellman, 2004, en Mayer, Schoors en Yafeh, 2005, bijvoorbeeld) wijst erop dat onafhankelijke participatiemaatschappijen meer investeren in ondernemingen die zich in vroege stadia van de bedrijfscyclus bevinden, terwijl participatiemaatschappijen die eigendom zijn van banken meer in latere stadia investeren en sterker geneigd zijn om hun bedrijven minder vaak te controleren. Om deze reden zal het gunstige effect van consolidatie waarschijnlijk vooral gevoeld worden in de latere stadia, wanneer de onderneming behoefte kan hebben aan additionele financiële middelen om op industriële schaal te produceren, om verbeteringen aan de installaties aan te brengen of later wanneer een verkoop of een Intitial Public Offering wordt voorbereid. Bankconsolidatie zal waarschijnlijk geen groter aanbod teweegbrengen van door banken gefinancierd durfkapitaal voor de vroege stadia waarin een onderneming de haalbaarheid van een project uitzoekt en waarin het start met het uittekenen van haar structuur en haar bedrijfsstrategie. Indirect kan de toegenomen beschikbaarheid van door banken gefinancierd durfkapitaal voor latere stadia er echter toe leiden dat andere durfkapitalisten zich meer toeleggen op de financiering van de vroege stadia. Hoewel het aanvan- kelijk een secundair effect betreft, kan het verschil in nadruk leiden tot specialisatie en verdere toenames in de beschikbaarheid van krediet.

Anderzijds zijn er ook verschillende beleidsdomeinen die niet rechtstreeks betrokken zijn bij de integratie van de financiële wereld die innovatie kunnen beïnvloeden. De aan de gang zijnde hervormingen van de pensioensystemen in verschillende Europese landen kunnen een positieve invloed hebben, al kan dit afhankelijk zijn van de regelgeving die van toepassing is voor investeringen door pensioenfondsen. In feite was het voor de Verenigde Staten de invoering in 1979 van een amendement op de 'Employee Retirement Income Security Act', waardoor managers van pensioenfondsen expliciet werd toegestaan in zeer riskante activa te investeren (met inbegrip van durfkapitaal), dat voor een enorme stijging zorgde van de financiële middelen die de markt voor durfkapitaal instromen.

\section{Conclusie}

In deze bijdrage richtten we ons op de vraag of kleine ondernemingen beïnvloed worden door de integratie van de Europese financiële sector. De integratie van de Europese bankwereld via deregulering en technologische vooruitgang heeft voornamelijk geleid tot meer intense concurrentie op de bankmarkt, maar ook tot binnenlandse bankenconsolidatie. Een fellere concurrentie tussen banken kan de cruciale tijdelijke risicospreiding tussen banken en innoverende bedrijven ondermijnen. Bankconsolidatie leidt tot grotere banken die niet bereid of niet bekwaam kunnen zijn om de leningsaanvragen van kleine, innoverende ondernemingen af te handelen aangezien de bestaande informatie uit de relatie tussen bank en onderneming kan vervagen.

Wanneer we echter het bestaande bewijsmateriaal in ogenschouw nemen, concluderen we dat (1) concurrentie en relatiebankieren niet noodzakelijk tegenpolen hoeven te zijn en dat (2) gebaseerd op bewijsmateriaal uit de VS en recent bewijsmateriaal voor Italië, uiteindelijk andere bestaande of nieuwe banken de afgenomen kredietbeschikbaarheid mogelijk compenseren (hoewel ingangsbeperkingen hiervoor volledig dienen te worden verwijderd). De vraag blijft wel of de conclusies voor deze landen gelden voor andere landen wegens een aantal fundamentele verschillen in de organisatie van de bancaire markt. Daarnaast kan de groeiende Europese markt voor durfkapitaal een sleutelrol spelen in "het opvullen van het potentiële financieringshiaat". Meer in het bijzonder kan de consolidatie van de bankwereld tot 
grotere en meer gediversifieerde financiële instellingen leiden. Deze omvangrijke en complexe financiële instellingen kunnen meer van hun fondsen aan de markt voor durfkapitaal besteden. Momenteel lijken banken nochtans vooral de latere stadia binnen de markt voor durfkapitaal te ondersteunen.

\section{Literatuur}

Allen, F., en D. Gale, (1999), Diversity of Opinion and Financing of New Technologies, Journal of Financial Intermediation, vol. 8, pp. 68-89.

Angelini, P., R. Di Salvo, en G. Ferri, (1998), Availability and Cost of Credit for Small Businesses: Customer Relationships and Credit Cooperatives, Journal of Banking and Finance, vol. 22, pp. 925-954.

Berger, A.N., (2003), The Economic Effects of Technological Progress: Evidence from the Banking Industry, Journal of Money, Credit, and Banking, vol. 35, pp. 141-176.

Berger, A.N., S.D. Bonime, L.G. Goldberg, en L.J. White, (2004), The Dynamics of Market Entry: The Effects of Mergers and Acquisitions on Entry in the Banking Industry, Journal of Business, vol. 77, pp. 797-834.

Berger, A.N., N.M. Miller, M.A. Petersen, R.G. Rajan, en J.C. Stein, (2005), Does Function Follow Organizational Form? Evidence From the Lending Practices of Large and Small Banks, Journal of Financial Economics, vol. 76, pp. 237-269.

Berger, A.N., A. Saunders, J.M. Scalise, en G.F. Udell, (1998), The Effects of Bank Mergers and Acquisistions on Small Business Lending, Journal of Financial Economics, vol. 50, pp. 187-230.

Berger, A.N., en G.F. Udell, (1996), Universal Banking and the Future of Small Business Lending, in: A. Saunders, en W. Ingo, eds.: Financial System Design: The Case for Universal Banking (Irwin Publishing, Homewood IL).

Bonaccorsi Di Patti, E., en G. Gobbi, (2005), Winners or Losers? The Effects of Banking Consolidation on Corporate Borrowers, Journal of Finance, Forthcoming.

Boot, A.W.A., en A.V. Thakor, (2000), Can Relationship Banking Survive Competition?, Journal of Finance, vol. 55, pp. 679-713.

Bottazzi, L., M. Da Rin, en T. Hellman, (2004), The Changing Face of the European Venture Capital Industry: Facts and Analysis, Journal of Private Equity, vol. 7, pp. 26-53.

Carletti, E., (2004), The Structure of Bank Relationships, Endogenous Monitoring, and Loan Rates, Journal of Financial Intermediation, vol. 13, pp. 58-86.

Claessens, S., en L. Laeven, (2004), What Drives Bank Competition? Some International Evidence, Journal of Money, Credit, and Banking, vol. 36, pp. 563-583.

Da Rin, M., G. Nicodano, en A. Sembenelli, (2005), Public Policy and the Creation of Active Venture Capital Markets, Journal of Public Economics Forthcoming.

Degryse, H., N. Masschelein, en J. Mitchell, (2005), SMEs and Bank Lending Relationships: the Impact of Mergers," CentER - Tilburg University, Mimeo.

Degryse, H., en S. Ongena, (2006), Competition and Regulation in the Banking Sector: A Review of the Empirical Evidence on the Sources of Bank Rents, in: CentER - Tilburg University, Mimeo.

Degryse, H., S. Ongena, en M.F. Penas, (2006), Consolidation of the
European Banking Sector: Impact on Innovation, in Luc Renneboog, ed.: Advances in Corporate Finance and Asset Pricing (North Holland/ Elsevier, London), pp. 161-186.

Detragiache, E., P.G. Garella, en L. Guiso, (2000), Multiple versus Single Banking Relationships: Theory and Evidence, Journal of Finance, vol. 55 , pp. 1133-1161.

DeYoung, R., L.G. Goldberg, en L.J. White, (1999), Youth, Adolescence, and Maturity of Banks: Credit Availability to Small Business in an Era of Banking Consolidation, Journal of Banking and Finance, vol. 23, pp. 463-492.

Fama, E.F., (1985), What's Different about Banks?, Journal of Monetary Economics, vol. 15, pp. 5-29.

Focarelli, D., en F. Panetta, (2003), Are Mergers Beneficial to Consumers? Evidence from the Market for Bank Deposits, American Economic Review, vol. 93, pp. 1152-1171.

Garmaise, M.J., en T.J. Moskowitz, (2006), Bank Mergers and Crime: The Real and Social Effects of Credit Market Competition, Journal of Finance, vol. 61, pp. 495- 538.

Giannetti, M., en S. Ongena, (2005), Financial Integration and Entrepreneurial Activity: Evidence from Foreign Bank Entry in Emerging Markets, Center for Economic Policy Research, Working Paper.

Gilbert, R.A., en A.M. Zaretsky, (2003), Banking Antitrust: Are the Assumptions Still Valid?, Review of the Federal Reserve Bank of St. Louis, vol. 85, no. 6 (November/December), pp. 29-52.

Gompers, P., en J. Lerner, (1999), What Drives Venture Capital Fundraising?," National Bureau for Economic Research, Working Paper.

Hellmann, T., L. Lindsay, en M. Puri, (2005), Building relationships early: Banks in Venture Capital, UBC, Mimeo.

Herrera, A.M., en R. Minetti, (2005), Informed Finance and Technological Change: Evidence from Credit Relationships, Michigan State University, Mimeo.

Karceski, J., S. Ongena, en D.C. Smith, (2005), The Impact of Bank Consolidation on Commercial Borrower Welfare, Journal of Finance, vol. 60, pp. 2043-2082.

Mayer, C., K. Schoors, en Y. Yafeh, (2005), Sources of Funds and Investment Activities of Venture Capital Funds: Evidence from Germany, Israel, Japan and the United Kingdom," Journal of Corporate Finance, vol. 11, pp. 586-608.

Mortimer-Schutts, I., (2005), EU Regulatory and Supervisory Convergence: The Case for a Dual System with Choice, AEI-Brookings Joint Center for Regulatory Studies, Policy Discussion Paper.

Ongena, S., en D.C. Smith, (2000), What Determines the Number of Bank Relationships? Cross-Country Evidence, Journal of Financial Intermediation, vol. 9, pp. 26-56.

Peek, J., en E.S. Rosengren, (1996), Small Business Credit Availability: How Important Is the Size of Lender?, in: A. Saunders, en W. Ingo, eds.: Financial System Design: The Case for Universal Banking (Irwin Publishing, Homewood IL).

Petersen, M.A., en R.G. Rajan, (1995), The Effect of Credit Market Competition on Lending Relationships, Quarterly Journal of Economics, vol. 110, pp. 406-443.

Petersen, M.A., en R.G. Rajan, (2002), Does Distance Still Matter? The Information Revolution in Small Business Lending, Journal of Finance, 
vol. 57, pp. 2533-2570.

Sapienza, P., (2002), The Effects of Banking Mergers on Loan Contracts Journal of Finance, vol. 57, pp. 329-368.

Stein, J., (2002), Information Production and Capital Allocation: Decentralized versus Hierarchical Firms, Journal of Finance, vol. 57, pp. 1891-1922.

Strahan, P., (2005), Bank Structure and Lending: What We Do and Do Not Know, in A.W.A. Boot, en A.V. Thakor, eds.: Handbook of Corporate Finance: Financial Intermediation and Banking (North Holland, London), Forthcoming.

Von Rheinbaben, J., en M. Ruckes, (2004), The Number and the Closeness of Bank Relationships, Journal of Banking and Finance, vol. 28, pp. 15971615.

\section{Noten}

1 Dit artikel baseert zich ten dele op de volgende twee bijdragen: Degryse H., S. Ongena en F. Penas, 2005, Between Lisbon en London: Financial sector consolidation in the context of the Lisbon agenda, AEl-Brookings Joint Center, Policy Brief 05-33, en Degryse H., S. Ongena en F. Penas, 2006, Consolidation of the European banking sector: Impact on innovation, in Renneboog, L. (ed.), Advances in Corporate Finance en Asset Pricing, Ch. 6 .

2 De Herfindahl-Hirschman Index (HHI) is een maatstaf van marktconcentratie en is de som van de gekwadrateerde marktaandelen van alle banken in de markt.

3 We hanteren sterren om de significantie van de coëfficiënten aan te geven: ${ }^{* * *}$ significant op $1 \%,{ }^{* *}$ significant op $5 \%$ en ${ }^{*}$ significant op $10 \%$.

4 Berger, Miller, Petersen, Rajan en Stein (2005) levert waardevol bewijs dat elementen van Steins model bevestigt. Zo stellen ze dat grote banken minder exclusieve en kortere relaties hebben en onpersoon lijker omgaan met hun leners.

5 De $\mathrm{H}$-statistiek is de som van de elasticiteiten van de interestopbrengsten vis-à-vis de inputfactoren.

6 Gompers en Lerner (1999) stelt hetzelfde vast voor de vS en geeft hiervoor een verklaring aan de vraagzijde: een daling in de vermogensaanwasbelasting geeft werknemers meer prikkels om ondernemer te worden. 